\title{
An enzyme-linked immunosorbent-assay test for hepatitis B surface antigen
}

\author{
ELISE M. VANDERVELDE, B. J. COHEN, AND YVONNE E. COSSART \\ From the Virus Reference Laboratory, Central Public Health Laboratory, Colindale Avenue, \\ London NW9 5 HT
}

SUMMARY A new commercial test for hepatis B surface antigen based on an enzyme-linked immunosorbent-assay system was evaluated and compared with other tests already available. It was of comparable sensitivity to the radioimmunoassay test but required less expensive equipment(in terms of both outlay and upkeep) and did not use radioisotopes; the reagents were more stable.

The third phase tests for hepatitis B surface antigen (HBsAg)-passive haemagglutination (pHA) and radioimmunoassay (RIA) - are now well established. Although regarded as the most sensitive and most specific, the RIA test has its disadvantages; it is expensive, the reagents have a short shelf-life, and it requires specialised equipment and radiological protection.

Enzyme-linked immunosorbent assays were devised by Engvall and Perlmann (1971) and their wide application has been indicated by Voller et al. (1976). An assay of this type was developed by Wolters $e t$ al. (1976) for HBsAg detection. The Virus Reference Laboratory was able to assess its performance as part of an organised multicentred study (Kacaki et al., 1977b) before the reagents were available commercially.

\section{Material and methods}

\section{TECHNIQUES}

A commercial ELISA test system (Hepanostika) developed by Organon Scientific Development Group was used as described by Wolters et al. (1976). It was available in microtitre plates and the results were read visually. A positive reaction was visible as a yellow colour which was easily read by eye against a diffuse light source placed under the microtitre plate. Each plate included two $\mathrm{HBsAg}$ positive controls (a weak and a strong) and one HBsAg negative control. A specimen was regarded as $\mathrm{HBsAg}$ positive when the colour produced was stronger than that of the negative control.

At first the specificity test recommended for con-

Received for publication 26 April 1977 firming specimens which produced a positive result on screening involved a neutralisation procedure (using human anti-HBs serum and a control nonimmune serum), after which the test was repeated, including repeat testing of the undiluted sample. This was later modified to a simpler procedure wherein anti-HBs was added to the sample in the plate (Kacaki et al., 1977a).

All the reagents except the sulphuric acid were supplied with the test and required only dilution or reconstitution at the time of the test.

Electrophoresis (IEOP) was performed as previously described (Pesendorfer et al., 1970). HA tests-Hepanosticon (Organon Teknika) and Hepatest (Wellcome Reagents), RIA Ausria II (Abbott Laboratories) - were carried out according to the manufacturers' instructions.

\section{SPECIMENS}

Two HBsAg positive sera of known subtype ( $\mathrm{ad}$ and ay) were used to assess the sensitivity and specificity of the test.

Two hundred and seventy-six samples froma 'highrisk' group of specimens were tested. 'High risk' included patients with chronic liver discase, patients recovering from a proven attack of acute hepatitis $B$, haemophiliacs, patients in institutions, and ihose who had given equivocal results with other tests.

Four hundred and ninety-seven received for routine testing were also screened. These were selected from consecutive specimens submitted to the laboratory, the only criterion for selection being that there was sufficient material for confirmation of aberrant results.

All but seven specimens were sera. Of the remainder, six were commercial factor VIII concen- 
Table 1 Comparison of Hepanosticon and ELISA tests

\begin{tabular}{llllll}
\hline & Total & HA - ELISA & HA+ELISA+ & HA - ELISA+ & HA + ELISA - \\
\hline 'High risk' & 276 & $223(81 \%)$ & $16(5 \cdot 7 \%)$ & $35(12 \cdot 6 \%)$ & $2(0 \cdot 7 \%)$ \\
Routine & 497 & $471(94 \cdot 8 \%)$ & $22(4 \cdot 4 \%)$ & $4(0 \cdot 8 \%)$ & 0 \\
Total & 773 & $694(89 \cdot 75 \%)$ & $38(5 \%)$ & $39(5 \%)$ & $2(0 \cdot 25 \%)$ \\
\hline
\end{tabular}

Table 2 Comparative titration of prototype $\mathrm{HBs}$ antigens by different methods

\begin{tabular}{lll}
\hline Method & \multicolumn{2}{l}{ Antigen specimen } \\
\cline { 2 - 3 } & Subtype ad & Subtype ay \\
\hline IEOP & $1 / 16$ & $1 / 128$ \\
HA (Hepanosticon) & $1 / 400$ & $1 / 1600$ \\
HA (Hepatest) & $1 / 1600$ & $1 / 1280$ \\
HA (Auscell) & $1 / 1600$ & $1 / 3200$ \\
RIA (Ausria II) & $1 / 32000$ & $1 / 16000$ \\
ELISA & $1 / 51200$ & $1 / 160000$ \\
\hline
\end{tabular}

trates and one was urine from a patient with glomerulonephritis and $\mathrm{HBsAg}$ in the serum.

\section{Results}

The sensitivity of the ELISA system when used to titrate sera of ad and ay subtypes was greater than the Ausria II system (Table 2). However, the titres detected were so high that in routine practice this difference is probably not significant.

Of the total of 773 specimens tested, 38 were positive by both Hepanosticon and ELISA (Table 1) ( 25 of these were also positive by electrophoresis). A further 39 were negative by Hepanosticon but positive by ELISA; 28 of these were convalescent specimens from proven cases of hepatitis $B$ taken 3 to 13 weeks after onset. Of these, all but one (taken one month after the onset of acute hepatitis B) were positive by Ausria II and/or Hepatest. Another three specimens from patients recovering from acute hepatitis B which were negative by both Hepanosticon and ELISA were weakly positive by RIA. The two specimens positive by Hepanosticon but negative by ELISA were also negative by Hepatest and RIA. However, they were both heterophil antibody positive (Paul-Bunnell test) and were from clinical cases of infectious mononucleosis with mild jaundice.

The urine from the seropositive patient with glomerulonephritis was positive by both ELISA and RIA but negative by Hepanosticon.

The factor VIII concentrates were all negative by ELISA (although one which was positive on the initial screening test was negative when repeated and tested for specificity). In the Ausria II test all had ratios above 1 but only one was above $2 \cdot 1$-the level regarded as significant when serum is tested.

\section{Discussion}

This new enzyme-linked immunosorbent-assay test is comparable in sensitivity and specificity with RIA. Unlike RIA it does not require radiological protection and expensive equipment (although an automatic washer/aspirator is most useful). An automatic dispenser originally supplied proved to be unsatisfactory but multichannel pipettes facilitating the dispensing of conjugate, substrate, and sulphuric acid are now available. Thus the system can be automated and should prove suitable for testing large numbers of specimens. Each plate can be used for testing about 100 specimens but, if necessary, unused wells can be used in a second run provided they are sealed during the first run and used within one week. The reagents have a shelf-life of about one year (compared with the three weeks of Ausria II). As with Ausria II a relatively long incubation period is required, although the overnight period at room temperature can be reduced to 2 hours at $37^{\circ} \mathrm{C}$. As the time taken to read the results is very much shorter than with Ausria II, results can be made available on the day of testing. However, both Ausria II and ELISA in their present format are not suitable for testing the single urgent specimen.

\section{References}

Engvall, E. and Perlmann, P. (1971). Enzyme-linked immunosorbent assay (ELISA): quantitative assay of immunoglobulin G. Immunochemistry, 8, 871-874.

Kacaki, J., Wolters, G., Kuijpers, L., and Schuurs, A. (1977a). Specificity control in the solid-phase enzyme immunoassay for HBsAg by one-step in situ blocking with human anti-HBs. Journal of Clinical Pathology. In press.

Kacaki, J., Wolters, G., Kuijpers, L., and Stulemeyer, S. (1977b). Results of the multicentre clinical trial of the solid-phase enzyme-immunoassay for HBsAg. In press.

Pesendorfer, F., Krassnitsky, O., and Wewalka, F. G. (1970). Viral hepatitis and tests for the Australia (hepatitis-associated) antigen and antibody. V. Immunoelectrophoretic methods. Bulletin of the World Health Organization, 42, 974-975. 
Voller, A., Bidwell, D. E., and Bartlett, A. (1976). Enzyme immunoassays in diagnostic medicine: theory and practice. Bulletin of the World Health Organization, 53, 55-65.
Wolters, G., Kuijpers, L., Kačaki, J., and Schuurs, A. (1976). Solid-phase enzyme-immunoassay for detection of hepatitis B surface antigen. Journal of Clinical Pathology, 29, 873-879. 